\title{
TINJAUAN YURIDIS TERHADAP PENOLAKAN PEMBAYARAN UTANG OLEH KREDITOR PADA SAAT PERMOHONAN PAILIT DIAJUKAN (Studi Kasus: Kepailitan PT. Hendratna Plymood)
}

\author{
Oleh: \\ Nur Fauzia *
}

\begin{abstract}
ABSTRAK
Suatu usaha tidak selalu berjalan dengan baik dan lancar, sering kali keadaan keuangan pelaku usaha tersebut sudah sedemikian rupa hingga sampai pada suatu keadaan dimana pelaku usaha tidak mampu lagi membayar utang- utangnya yang telah jatuh tempo. Para Kreditor yang mengetahui bahwa Debitor tidak mampu lagi membayar utang-utangnya akan berusaha untuk terlebih dahulu mendapatkan pelunasan atas piutangnya. Para kreditor mungkin saja memaksa debitornya untuk menyerahkan barang-barang guna pelunasan hutang-hutangnya, atau dapat juga debitor diminta untuk melakukan perbuatan yang hanya menguntungkan satu atau beberapa kreditor saja sedangkan kreditor yang lainnya dirugikan. Tindakan Kreditor atau perlakuan Debitor yang demikian jelas akan memberikan ketidakpastian bagi Kreditor lain yang beritikad baik yang tidak ikut mengambil barangbarang Debitor sebagai pelunasan piutangnya, sehingga piutang Kreditor yang beritikad baik tersebut tidak terjamin pelunasannya. Berdasarkan hal-hal tersebut di atas, maka dibutuhkan suatu lembaga yang dapat menyelesaikan masalah dan dapat memberikan suatu kepastian hukum, sehingga kejadian-kejadian sebagaimana disebut di atas dapat dicegah. Salah satu contoh kasus penyelesaian utang Debitor terhadap Kreditor melalui kepailitan yang dalam prosesnya kurang tepat dalam menerapkan ketentuan syarat permohonan pailit dalam UU No.37 Tahun 2004 adalah kasus kepailitan PT. Hendratna Plywood dengan para Kreditornya yaitu PT. Ocean Global Shipping dan PT. Samudra Naga Global. Dimana PT. Hendratna Plywood membayar hutangnya kepada salah satu Kreditornya, yakni PT. Samudra Naga Global pada saat 14 (empat belas) hari setelah permohonan pailit didaftarkan di Pengadilan Niaga Jakarta Pusat. Dengan adanya pembayaran tersebut, syarat kepailitan dalam UU No. 37 Tahun 2004 yaitu adanya 2 (dua) kreditor atau lebih dan suatu utang yang telah jatuh tempo dan dapat ditagih menjadi tidak terpenuhi lagi. Lebih lanjut hal tersebut menimbulkan permasalahan yaitu dimana PT. Hendratna Plywood yang telah membayar utangnya menuntut agar kepailitan dibatalkan. Sedangkan PT. Ocean Global Shipping menuntut agar PT. Hendratna Plywood tetap dipailitkan meskipun utang terhadap salah satu Kreditor telah dibayar lunas. Namun pada akhirnya Pengadilan Niaga pada Pengadilan Negeri Jakarta Pusat dengan putusan No. 16/2010. Pailit/PN.Niaga.Jkt.Pst menjatuhkan putusan pailit kepada PT. Hendratna Plywood dengan segala akibat hukumnya.
\end{abstract}

Kata Kunci : Utang, Pailit, Kreditor, PT. Hendratna Plymood

\section{A. Latar Belakang}

Pertumbuhan dan perkembangan perekonomi di Indonesia pada prinsipnya tidak dapat dipisahkan dari peranan para pelaku-pelaku ekonomi yang melakukan kegiatan bisnis di Indonesia. Para pelaku-pelaku ekonomi dapat tumbuh dan berkembang dengan baik oleh

\footnotetext{
* Pengajar Fakultas Hukum UNBARI
} 
Nur Fauzia, Tinjauan Yuridis Terhadap Penolakan Pembayaran Utang Oleh Kreditor Pada Saat Permohonan Pailit Diajukan (Studi Kasus: Kepailitan PT. Hendratna Plymood)

karena tersedianya beberapa faktor penunjang serta iklim berusaha yang mendukung. Adapun faktor-faktor penunjang tersebut antara lain adalah ${ }^{1}$ : sumber daya manusia, sumber daya alam, ilmu pengetahuan dan tekonologi, budaya, dan sumber daya modal. Di antara faktor-faktor tersebut di atas, faktor yang sangat penting adalah sumber daya modal, mengingat modal merupakan motor pengerak bagi kegiatan dunia usaha pada umumnya.

Setiap organisasi ekonomi dalam bentuk dan skala apapun selalu membutuhkan dana cukup agar laju kegiatan usahanya dapat terwujud sesuai dengan perencanaannya. Kebutuhan dana, adakalanya dapat dipenuhi sendiri (internal) sesuai dengan kemampuan pemilik usaha, akan tetapi adakalanya tidak dapat dipenuhi sendiri. Untuk itu dibutuhkan dana bantuan dari pihak lain (eksternal) yang bersedia membantu menyediakan dana dengan cara meminjam atau berutang kepada pihak lain.

Utang dalam dunia usaha adalah suatu hal yang biasa dilakukan oleh pelaku usaha pada umumnya baik perorangan maupun badan usaha. Para pelaku usaha yang masih dapat membayar kembali utang-utangnya disebut sebagai pelaku usaha yang solvable. Sebaliknya pelaku usaha yang sudah tidak dapat membayar utang- utangnya disebut insolvable, atau dalam keadaan tidak mampu lagi untuk membayar.

Suatu usaha tidak selalu berjalan dengan baik dan lancar, sering kali keadaan keuangan pelaku usaha tersebut sudah sedemikian rupa hingga sampai pada suatu keadaan dimana pelaku usaha tidak mampu lagi membayar utang- utangnya yang telah jatuh tempo. Para Kreditor yang mengetahui bahwa Debitor tidak mampu lagi membayar utang-utangnya akan berusaha untuk terlebih dahulu mendapatkan pelunasan atas piutangnya.

Para kreditor mungkin saja memaksa debitornya untuk menyerahkan barang-barang guna pelunasan hutang-hutangnya, atau dapat juga debitor diminta untuk melakukan perbuatan yang hanya menguntungkan satu atau beberapa kreditor saja sedangkan kreditor yang lainnya dirugikan. Tindakan Kreditor atau perlakuan Debitor yang demikian jelas akan memberikan ketidakpastian bagi Kreditor lain yang beritikad baik yang tidak ikut mengambil barang-barang Debitor sebagai pelunasan piutangnya, sehingga piutang Kreditor yang beritikad baik tersebut tidak terjamin pelunasannya. Berdasarkan hal-hal tersebut di atas, maka dibutuhkan suatu lembaga yang dapat menyelesaikan masalah dan dapat memberikan suatu kepastian hukum, sehingga kejadian-kejadian sebagaimana disebut di atas dapat dicegah. Adapun lembaga ini dikenal pula dengan istilah lembaga kepailitan.

\footnotetext{
1 Herlan Firmansyah, "Bahan Kuliah : Pertumbuhan blogspot.com/2009/04/bahan-kuliah-pertumbuhan-ekonomi.html, 2 September 2019

Ekonomi”, http://erlan-abuhanifa.
} 
Nur Fauzia, Tinjauan Yuridis Terhadap Penolakan Pembayaran Utang Oleh Kreditor Pada Saat Permohonan Pailit Diajukan (Studi Kasus: Kepailitan PT. Hendratna Plymood)

Berkaitan dengan hal tersebut di atas, Sri Redjeki Hartono mengatakan bahwa:

"Lembaga kepailitan memberikan suatu solusi terhadap para pihak apabila Debitor dalam keadaan berhenti membayar/tidak mampu membayar. Lembaga kepailitan mencegah/menghindari dua hal berikut, yang keduanya merupakan tindakan-tindakan yang tidak adil dan dapat merugikan semua pihak, yaitu: menghindari eksekusi masal oleh Debitor atau Kreditor dan mencegah terjadinya kecurangan oleh Debitor sendiri." 2

Menurut Sutan Remy Sjahdeini, hukum kepailitan diperlukan untuk mengatur mengenai cara pembagian hasil penjualan harta debitor untuk melunasi piutang masingmasing kreditor berdasarkan urutan prioritasnya. Sebelum dibagikan kepada para kreditor, harta debitor oleh pengadilan diletakkan terlebih dahulu di bawah sita umum. ${ }^{3}$

Sejarah hukum kepailitan di Indonesia berawal sejak tahun 1905, yaitu dengan adanya pengaturan kepailitan dalam "Verordening op Het Failissement en Surseance van Betaling vor de European in Indonesia"4 (Failissement Verordening, Peraturan Kepailitan), Staatsblad 1905 Nomor 217 juncto Staatsblad 1906 nomor 348. Faillissement verordening selanjutnya disingkat FV di Indonesia, yang berlaku bagi orang-orang yang tunduk pada Hukum Perdata Barat dan juga untuk orang-orang yang menundukkan diri pada Hukum Perdata Barat. ${ }^{5}$ Kemudian setelah Indonesia merdeka pada tanggal 17 Agustus 1945, FV dinyatakan tetap berlaku berdasarkan Pasal II Aturan Peralihan Undang-Undang Dasar 1945.

Pada tanggal 22 April 1998, Pemerintah Indonesia menyempurnakan peraturan kepailitan tersebut dengan mengundangkan Undang-Undang Nomor 4 Tahun 1998 tentang Penetapan Peraturan Pemerintah Pengganti Undang-Undang Nomor 1 Tahun 1998 tentang Perubahan atas Undang-Undang Kepailitan menjadi Undang-Undang. ${ }^{6}$

Undang-Undang Nomor 4 Tahun 1998 ini tidaklah mencabut FV, tetapi hanya menambah dan merubahnya. Dibuatnya Undang-Undang Nomor 4 Tahun 1998 ini adalah untuk memenuhi isi Letter of Intent yang telah ditandatangani antara pemerintah Indonesia dengan International Moneter Fund ("IMF"), sebagai syarat bagi Indonesia untuk

\footnotetext{
${ }^{2}$ Sri Redjeki Hartono, Hukum Perdata Sebagai Dasar Hukum Kepailitan Modern, JurnalHukum Bisnis, Volume 7 , Jakarta: Yayasan Pengembangan Hukum Bisnis, 1999. hal. 22

3 Emmy Yuhassarie,"Undang-Undang Kepailitan dan Perkembangannya," Makalah disampaikan pada Lokakarya Terbatas Makalah-Makalah Kepailitan dan Wawasan Hukum Bisnis Lainnya, Jakarta 26 - 28 Januari 2004, hal. XV

${ }^{4}$ Sutan Remi Sjahdeini, Hukum Kepailitan: Memahami Failissement Verording Juncto Undang-Undang nomor 4 tahun 1998; Jakarta: Pustaka Grafiti Utama, 2002, hal 1

${ }^{5}$ Man S. Sastrawidjaja, Hukum Kepailitan dan Penundaan Kewajiban Pembayaran Utang, Bandung : P.T. Alumni, 2006, hal. 7

6 "Sejarah hukum kepailitan", http://www.slideshare.net/joehasan/sejarah-hukum-kepailitan-di-indonesia, 2 September 2019
} 
Nur Fauzia, Tinjauan Yuridis Terhadap Penolakan Pembayaran Utang Oleh Kreditor Pada Saat Permohonan Pailit Diajukan (Studi Kasus: Kepailitan PT. Hendratna Plymood)

memperoleh dana pinjaman dari IMF. ${ }^{7}$ Pada tanggal 18 Oktober 2004 diundangkannya Undang-Undang Nomor 37 Tahun 2004 tentang Kepailitan dan Penundaan Kewajiban Pembayaran Utang, dimana hal tersebut menyebabkan Undang-Undang Nomor 4 Tahun 1998 dinyatakan tidak berlaku lagi. Adapun tujuan dari dibentuknya Undang-Undang Kepailitan tersebut adalah untuk mewujudkan penyelesaian masalah utang piutang secara cepat, adil, terbuka dan efektif. ${ }^{8}$

Menurut Pasal 1 ayat (1) Undang-Undang Nomor 37 Tahun 2004 tentang Kepailitan dan Penundaan Kewajiban Pembayaran Utang (untuk selanjutnya disebut "UU No. 37 Tahun 2004”):

"Kepailitan adalah sita umum atas semua kekayaan Debitor Pailit yang pengurusan dan pemberesannya dilakukan oleh Kurator di bawah pengawasan Hakim Pengawas sebagaimana diatur dalam Undang-Undang ini.",

Kepailitan pada dasarnya merupakan realisasi dari dua asas pokok yang terkandung dalam Pasal 1131 dan Pasal 1132 Kitab Undang-Undang Hukum Perdata.

Pasal 1131 KUH Perdata menyatakan bahwa:

"Segala kebendaan si berutang, baik bergerak maupun tidak bergerak, baik yang sudah ada maupun yang baru ada dikemudian hari menjadi tanggungan untuk segala perikatan perseorangan."

Pasal 1132 KUH Perdata menyatakan bahwa:

"Kebendaan tersebut menjadi jaminan bersama bagi semua orang yang mengutangkan padanya, pendapatan penjualan benda-benda itu dibagi-bagi menurut keseimbangan, yaitu menurut besar kecilnya piutang masing-masing, kecuali apabila diantara para berpiutang itu ada alasan-alasan yang sah untuk didahulukan."

Kedua pasal tersebut di atas memberikan jaminan kepastian hukum kepada kreditor bahwa kewajiban debitor akan tetap dipenuhi dengan jaminan seluruh harta kekayaan debitor baik yang sudah ada maupun yang masih akan ada dikemudian hari atau yang lebih dikenal dengan istilah jaminan umum.

Kepailitan harus mengikuti syarat dan prosedur tertentu sebagaimana diatur dalam UU No. 37 Tahun 2004 sehingga Debitor dapat dinyatakan pailit dengan suatu keputusan Pengadilan. Syarat Debitor dapat dinyatakan pailit adalah apabila Debitor mempunyai dua

\footnotetext{
${ }^{7}$ Sjahjeini, Op.Cit., hal 35

8 Widjanarko, Dampak Implementasi Undang-Undang Kepailitan Terhadap Sektor Perbankan, Jurnal Hukum Bisnis, Volume 8, Jakarta: Yayasan Pengembangan Hukum Bisnis, 1999 hal 73
} 
Nur Fauzia, Tinjauan Yuridis Terhadap Penolakan Pembayaran Utang Oleh Kreditor Pada Saat Permohonan Pailit Diajukan (Studi Kasus: Kepailitan PT. Hendratna Plymood)

atau lebih Kreditor dan tidak membayar lunas sedikitnya satu utang yang telah jatuh waktu dan dapat ditagih. Permohonan pernyataan pailit harus diajukan kepada Pengadilan Niaga yang daerah hukumnya meliputi daerah tempat kedudukan hukum debitor.

Kepailitan dapat diajukan atas permohonan Debitor sendiri atau oleh seorang Kreditor maupun beberapa orang Kreditor, Kejaksaan untuk kepentingan umum, Bank Indonesia dalam hal Debitornya adalah Bank, Otoritas Jasa Keuangan (dahulu BAPEPAM) dalam hal Debitornya adalah Perusahaan Efek, Bursa Efek, Lembaga Kliring dan Penjamin, Lembaga Penyimpanan dan Penyelesaian, dan Menteri Keuangan dalam hal debitornya adalah Perusahaan Asurasi, Perusahaan Reasuransi, Perusahaan Pembiayaan, dan Dana Pensiun. Pailit adalah suatu keadaan di mana debitor tidak mampu untuk melakukan pembayaran-pembayaran terhadap utang-utang dari para kreditornya. ${ }^{9}$

Putusan pernyataan pailit mengubah status hukum seseorang menjadi tidak cakap untuk melakukan perbuatan hukum, menguasai, dan mengurus harta kekayaannya lagi sejak dijatuhkannya putusan pernyataan pailit tersebut. Dengan adanya putusan pernyataan pailit ini, akan mempengaruhi credietwaardigheid debitor, artinya adalah si debitor tidak akan mudah mendapatkan kredit. ${ }^{10}$

Ada beberapa faktor penting dibuatnya suatu peraturan mengenai kepailitan dan penundaan kewajiban pembayaran utang, yaitu:

a. Untuk menghindari perebutan harta Debitor apabila dalam waktu yang sama ada beberapa Kreditor yang menagih piutangnya kepada Debitor.

b. Untuk menghindari adanya Kreditor pemegang hak jaminan kebendaan yang menuntut haknya dengan cara menjual barang milik Debitor tanpa memperhatikan kepentingan Debitor atau para Kreditor lainnya.

c. Untuk menghindari adanya kecurangan-kecurangan yang dilakukan oleh salah seorang Kreditor atau Debitor sendiri. Misalnya, Debitor berusaha untuk memberi keuntungan kepada seorang atau beberapa orang Kreditor tertentu sehingga Kreditor lainnya dirugikan, atau adanya perbuatan curang dari Debitor untuk melarikan semua harta kekayaannya dengan maksud untuk melepaskan tanggung jawabnya terhadap para Kreditor.

Untuk dapat dimohonkan pailit, UU No. 37 Tahun 2004 mewajibkan bahwa seorang Debitor yang mempunyai 2 (dua) atau lebih Kreditor dan tidak membayar lunas

\footnotetext{
${ }^{9}$ M. Hadi Shubhan, “Hukum Kepailitan: Prinsip, Norma dan Praktek di Pengadilan,” Jakarta: Kencana, 2009. hal. 1

${ }^{10}$ Kartono, Kepailitan dan Pengunduran Pembayaran, Jakarta: Pridnya Paramita, 1982, hal 42
} 
sedikitnya 1 (satu) utang yang sudah jatuh waktu dan dapat ditagih, dapat dinyatakan pailit dengan putusan Pengadilan, baik atas permohonannya sendiri maupun atas permohonan satu atau lebih Kreditornya. UU No. 37 Tahun 2004 telah mengatur secara tegas tentang syarat permohonan pailit terhadap Debitor, akan tetapi dalam praktek atau kenyataannya ada beberapa putusan pengadilan yang kurang tepat dalam menerapkan syarat permohonan pailit tersebut di atas. ${ }^{11}$

Salah satu contoh kasus penyelesaian utang Debitor terhadap Kreditor melalui kepailitan yang dalam prosesnya kurang tepat dalam menerapkan ketentuan syarat permohonan pailit dalam UU No.37 Tahun 2004 adalah kasus kepailitan PT. Hendratna Plywood dengan para Kreditornya yaitu PT. Ocean Global Shipping dan PT. Samudra Naga Global. Dimana PT. Hendratna Plywood membayar hutangnya kepada salah satu Kreditornya, yakni PT. Samudra Naga Global pada saat 14 (empat belas) hari setelah permohonan pailit didaftarkan di Pengadilan Niaga Jakarta Pusat.

Dengan adanya pembayaran tersebut, syarat kepailitan dalam UU No. 37 Tahun 2004 yaitu adanya 2 (dua) kreditor atau lebih dan suatu utang yang telah jatuh tempo dan dapat ditagih menjadi tidak terpenuhi lagi. Lebih lanjut hal tersebut menimbulkan permasalahan yaitu dimana PT. Hendratna Plywood yang telah membayar utangnya menuntut agar kepailitan dibatalkan. Sedangkan PT. Ocean Global Shipping menuntut agar PT. Hendratna Plywood tetap dipailitkan meskipun utang terhadap salah satu Kreditor telah dibayar lunas. Namun pada akhirnya Pengadilan Niaga pada Pengadilan Negeri Jakarta Pusat dengan putusan No. 16/2010. Pailit/PN.Niaga.Jkt.Pst menjatuhkan putusan pailit kepada PT. Hendratna Plywood dengan segala akibat hukumnya.

Berdasarkan latar belakang tersebut di atas, Penulis berkeinginan untuk melakukan penelitian terhadap kepailitan PT. Hendratna Plywood oleh para Kreditornya, PT. Samudra Naga Global dan PT. Ocean Global Shipping. yang berjudul, “Tinjauan Yuridis Terhadap Penolakan Pembayaran Utang Oleh Kreditor Pada Saat Permohonan Pailit Diajukan (Studi Kasus: Kepailitan PT. Hendratna Plywood)".

\section{B. Rumusan Masalah}

Berdasarkan latar belakang permasalahan yang telah diungkapkan di atas, rumusan yang akan dibahas dalam penelitian ini adalah:

\footnotetext{
${ }^{11}$ Parwoto Wignjo Sumarto, Hukum Kepailitan Pandang, Jakarta: PT.Tatanusa, 2003, hal 168
} 
Nur Fauzia, Tinjauan Yuridis Terhadap Penolakan Pembayaran Utang Oleh Kreditor Pada Saat Permohonan Pailit Diajukan (Studi Kasus: Kepailitan PT. Hendratna Plymood)

1) Bagaimanakah penerapan ketentuan Pasal 2 Ayat (1) Undang-Undang Nomor 37 Tahun 2004 tentang Kepailitan dan Penundaan Kewajiban Pembayaran Utang dalam proses kepailitan PT. Hendratna Plywood?

2) Apakah akibat hukum yang timbul dari pembayaran utang PT. Hendratna Plywood kepada PT. Samudra Naga Global terkait kepailitan yang sudah didaftarkan permohonan pailitnya di Pengadilan Niaga pada Pengadilan Negeri Jakarta Pusat?

\section{Penerapan ketentuan Pasal 2 Ayat (1) Undang-Undang Nomor 37 Tahun 2004 tentang Kepailitan dan Penundaan Kewajiban Pembayaran Utang Dalam Proses Kepailitan PT. Hendratna Plywood}

Suatu permohonan kepailitan dapat dikabulkan apabila telah memenuhi syaratsyarat kepailitan yang diatur di dalam Pasal 2 UU No. 37 Tahun 2004. Adapun syarat-syarat kepailitan dalam Pasal 2 UU No. 37 Tahun 2004 adalah debitor yang mempunyai dua atau lebih kreditor dan tidak membayar lunas sedikitnya satu utang yang telah jatuh waktu dan dapat ditagih, dinyatakan pailit dengan putusan pengadilan, baik atas permohonannya sendiri maupun atas permohonan satu atau lebih kreditornya.

Berdasarkan syarat-syarat kepailitan tersebut di atas, dapat dijabarkan bahwa agar debitor dapat dinyatakan pailit maka wajib dipenuhinya kriteria- kriteria sebagai berikut ${ }^{12}$ :

1. Adanya utang;

2. Minimal salah satu utang telah jatuh tempo;

3. Minimal salah satu utang dapat ditagih;

4. Adanya debitor;

5. Adanya kreditor;

6. Minimal adanya 2 (dua) kreditor atau lebih;

7. Pernyataan pailit dilakukan oleh pengadilan khusus yang disebut dengan Pengadilan Niaga; dan

8. Permohonan pernyataan pailit diajukan oleh pihak yang berwenang, yaitu:
a. Pihak Debitor sendiri;
b. Satu atau lebih Kreditor;
c. Jaksa untuk kepentingan umum;
d. Bank Indonesia jika debitornya bank;

\footnotetext{
${ }^{12}$ Munir Fuady, Op. Cit., hal. 8
} 
e. Bapepam (sekarang Otoritas Jasa Keuangan) jika debitornya perusahaan efek, bursa efek, lembaga kliring dan penjaminan, dan lembaga penyimpanan dan penyelesaian; atau

f. Menteri Keuangan jika debitornya perusahaan asuransi, reasuransi, dana pensiun, dan Badan Usaha Milik Negara yang bergerak di bidang kepentingan publik.

Apabila seluruh syarat-syarat yuridis kepailitan tersebut di atas terpenuhi, maka majelis hakim "menyatakan pailit” Debitor.

Dikaitkan dengan kasus kepailitan PT HPL, syarat-syarat yuridis kepailitan sebagaimana dimaksud di atas dapat dianalisis sebagai berikut:

\section{Adanya utang}

Utang adalah kewajiban yang dinyatakan atau dapat dinyatakan dalam jumlah uang baik dalam mata uang Indonesia maupun mata uang asing, baik secara langsung maupun yang akan timbul di kemudian hari atau kontinjen, yang timbul karena perjanjian atau undang-undang dan yang wajib dipenuhi oleh Debitor dan bila tidak dipenuhi memberi hak kepada Kreditor untuk mendapat pemenuhannya dari harta kekayaan Debitor.

Dapatkah suatu bill of lading dianggap sebagai perjanjian yang menimbulkan kewajiban yang dapat dinyatakan dalam jumlah uang? Bill of lading / surat muat atau yang lebih dikenal sebagai tanda terima barang - barang yang diberikan oleh pengangkut kepada pengirim barang. ${ }^{13}$ Berdasarkan pasal 506 Kitab Undang-Undang Hukum Dagang dinyatakan bahwa:

"bill of lading (konosemen) adalah suatu surat bertanggal, dimana si pengangkut menerangkan bahwa ia telah menerima barang barang tersebut untuk diangkutnya ke suatu tempat, tujuan tertentu dan menyerahkannya disitu kepada seseorang tertentu begitu pula menerangkan dengan syarat syarat apakah barang barang itu akan diserahkan"

Sebagai dokumen induk dalam pengangkutan laut, bill of lading atau konosemen mempunyai beberapa fungsi, yaitu:

a. sebagai tanda terima barang;

b. sebagai bukti pemilikan atas barang;

c. sebagai bukti perjanjian pengangkutan laut.

Setelah barang - barang dimuat di atas kapal, kemudian pengangkut menerbitkan bill of lading yang juga merupakan bukti bagi kepentingan si pengirim dan pengangkut tentang

${ }^{13}$ Penyelenggaraan Pengangkutan Barang Melalui Laut Menurut Undang-Undang Pelayaran Nmor 17 Tahun 2008, http://repository.usu.ac.id/bitstream/123456789/307/40/3/Chapter\%20II.pdf, 20 September2019 
Nur Fauzia, Tinjauan Yuridis Terhadap Penolakan Pembayaran Utang Oleh Kreditor Pada Saat Permohonan Pailit Diajukan (Studi Kasus: Kepailitan PT. Hendratna Plymood)

adanya perjanjian pengangkutan diantara mereka. Dalam United Nations Convertion on the Carriage of Goods by Sea tahun 1978, bill of lading adalah dokumen yang membuktikan adanya kontrak pengangkutan laut (contract of carriage by sea).

Salah satu fungsi bill of lading adalah sebagai bukti adanya perjanjian pengangkutan laut. Dan atas pengangkutan laut tersebut menimbulkan kewajiban yang dinyatakan dalam sejumlah uang yang dibuktikan dengan diterbitkannya suatu invoice. Dalam kasus PT HPL ini, PT OGS dan PT SNG membuktikan bahwa adanya utang dengan alat bukti berupa bill of lading dan invoice.

Bukti adanya utang dari PT OGS adalah sebagai berikut:
a. Bill of Lading (B/L) Nomor COSU 6002355140 tertanggal 2 Januari 2008;
b. Invoice Nomor 060896 tertanggal 17 Januari 2008 sebesar USD 20.200,-;
c. Invoice Nomor 060897 tertanggal 17 Januari 2008 sebesar Rp 100.000,-
Bukti adanya utang dari PT SNG adalah sebagai berikut:

a. Bill of Lading Nomor 086X000420 tertanggal 31 Desember 2007;

b. Bill of Lading Nomor 086Y000001 tertanggal 3 Januari 2008

c. Bill of Lading Nomor 086Y000148 tertanggal 21 April 2008;

d. Invoice Nomor 004118 sebesar USD 800,- dan USD 10,- tertanggal 4 Januari 2008;

e. Invoice Nomor 004117 sebesar USD 1250,- dan USD 10,- tertanggal 4 Januari 2008;

f. Invoice Nomor 004723 sebesar USD 800,- dan USD 10,- tertanggal 21 April 2008.

Berdasarkan uraian-uraian tersebut di atas, maka dapat disimpulkan bahwa syarat adanya utang telah terpenuhi dengan bill of lading dan invoice.

2. Minimal salah satu utang telah jatuh tempo

Utang yang telah jatuh waktu atau jatuh tempo dapat didefinisikan sebagai utang yang dengan lampaunya waktu penjadualan yang ditentukan di dalam perjanjian kredit itu, menjadi jatuh waktu dan karena itu pula kreditor berhak untuk menagihnya. ${ }^{14}$

Berdasarkan bukti berupa Invoice tersebut di atas, dapat disimpulkan bahwa PT OGS dan PT SNG secara nyata memiliki utang yang sudah jatuh tempo terhadap PT HPL.

3. Minimal salah satu utang dapat ditagih

Utang yang telah jatuh waktu dengan sendirinya menjadi utang yang dapat ditagih. Dengan demikian berdasarkan bukti berupa Invoice tersebut di atas, dapat disimpulkan bahwa

${ }^{14}$ Sultan Remy Sjahdeini, Hukum Kepailitan: Memahami Undang-Undang No. 37 Tahun 2004 tentang Kepailitam dan Penundaan Kewajiban Pembayaran Utang, Jakarta: Pustaka Utama Grafiti, 2009, hal 57 
Nur Fauzia, Tinjauan Yuridis Terhadap Penolakan Pembayaran Utang Oleh Kreditor Pada Saat Permohonan Pailit Diajukan (Studi Kasus: Kepailitan PT. Hendratna Plymood)

piutang milik PT OGS dan PT SNG terhadap PT HPL adalah utang yang dapat ditagih karena telah jatuh tempo / jatuh waktu.

4. Adanya debitor

Debitor dapat didefinisikan sebagai orang yang mempunyai utang karena perjanjian atau menurut undang-undang yang pelunasannya dapat ditagih di muka pengadilan. Dalam kasus ini PT HPL telah terbukti secara nyata memiliki utang terhadap PT OGS dan PT SNG, sehingga syarat adanya debitor telah terpenuhi.

5. Adanya kreditor

Kreditor dapat didefinisikan sebagai orang yang mempunyai piutang karena perjanjian atau menurut undang-undang yang pelunasannya dapat ditagih di muka pengadilan. PT OGS dan PT SNG telah terbukti secara nyata memiliki piutang terhadap PT HPL sebagaimana ternyata dalam bill of lading dan invoice tersebut di atas, sehingga syarat adanya kreditor telah terpenuhi.

6. Minimal ada 2 (dua) kreditor atau lebih

Berdasarkan dalil-dalil dan pembuktian dari kuasa hukum PT HPL sebagaimana telah dikutip penulis sebelumnya, dapat disimpulkan bahwa PT HPL telah membayar utangnya terhadap PT SNG sebesar USD 2870,- yang dibuktikan dengan Bukti Pembayaran PT HPL kepada PT SNG tanggal 19 Maret 2010 sebesar USD 2870,--

Namun menurut keterangannya, PT SNG menolak pembayaran tersebut berdasarkan Surat Pernyataan Direktur PT SNG tertanggal 22 Maret 2010 yang pada pokoknya berisi pernyataan penolakan setiap pembayaran / transfer yang dilakukan oleh PT HPL tanpa melalui mekanisme kepailitan.

Didukung dengan adanya 2 (dua) buah surat pernyataan berdasarkan Bukti Surat Pernyataan Rini Sutanto (Staff PT HPL dalam pailit) tertanggal 25 Januari 2011, dan bukti Surat Pernyataan Direktur Utama PT HPL (dalam pailit) Noor Hendratna tertanggal 26 Januari 2011, yang pada intinya kedua surat tersebut menyatakan bahwa terhitung sejak tanggal 19 Maret 2010 atau pada saat uang sebesar USD 2870,- tersebut ditransfer kepada PT SNG sampai dengan dibuatnya surat tersebut, uang yang telah dibayarkan tersebut tidak pernah dikembalikan kepada PT HPL, yang mana hal ini bertentangan dengan pernyataan penolakan pembayaran yang dikeluarkan oleh PT SNG sebelumnya.

Maka berdasarkan uraian tersebut Penulis menyimpulkan bahwa PT SNG telah melakukan penerimaan secara diam-diam atau telah memberikan persetujuan secara diam- 
Nur Fauzia, Tinjauan Yuridis Terhadap Penolakan Pembayaran Utang Oleh Kreditor Pada Saat Permohonan Pailit Diajukan (Studi Kasus: Kepailitan PT. Hendratna Plymood)

diam terhadap pembayaran yang telah dilakukan oleh PT HPL. Dimana berdasarkan ketentuan dalam Pasal 1347 Kitab Undang-Undang Hukum Perdata yang berbunyi:

"Hal-hal yang menurut kebiasaan selamanya diperjanjikan, dianggap secara diamdiam dimasukkan dalam perjanjian, meskipun tidak dengan tegas dinyatakan”.

Dan penjelasan Prof. Subekti dalam bukunya Hukum Perjanjian (2002: 40) yang menyatakan bahwa: “.... Hal-hal yang selalu diperjanjikan menurut kebiasaan dianggap secara diam-diam dimasukkan dalam perjanjian, meskipun tidak dengan tegas dinyatakan. Oleh karena dianggap sebagai diperjanjikan atau sebagai bagian dari perjanjian sendiri, maka hal yang menurut kebiasaan selalu diperjanjikan itu dapat menyingkirkan suatu pasal undang-undang yang merupakan hukum pelengkap”.

Berdasarkan uraian tersebut di atas dapat diketahui bahwa hal yang merupakan suatu kebiasaan dianggap secara diam-diam telah dimasukkan dalam perjanjian. Dimana dalam dunia bisnis atau perdagangan pada umumnya suatu utang dianggap telah lunas ketika dilakukan pembayaran oleh Debitor, tanpa harus menunggu dikeluarkannya suatu surat atau tanda bukti lunas dari Kreditor. Selain hal tersebut antara PT HPL dan PT SNG tidak pernah diperjanjikan bahwa pembayaran baru akan diterima ketika dikeluarkannya suatu surat atau tanda bukti lunas, sehingga sudah sepatutnya kebiasaan-kebiasaan dalam dunia bisnis atau perdagangan dianggap secara diam-diam dimasukkan ke dalam perjanjian di antara mereka yang mengakibatkan pembayaran oleh PT HPL kepada PT SNG adalah sah dan telah diterima dengan baik. Dengan persetujuan atau kesepakatan diam-diam itu, maka berlaku mutlaklah asas konsensualitas yang merupakan kekuatan undang-undang bagi para pihak.

Oleh karena PT SNG telah menerima secara diam-diam pembayaran utang yang dilakukan oleh PT HPL, maka berdasarkan hal tersebut di atas serta sesuai dengan ketentuan dalam Pasal 1381 Kitab Undang-Undang

Hukum Perdata yang berbunyi:

"Perikatan-perikatan hapus karena pembayaran; karena penawaran pembayaran tunai, diikuti dengan penyimpanan atau penitipian; karena pembaruan utang; karena perjumpaan utang atau kompensasi; karena percampuran utang; karena pembebasan utang; karena musnahnya barang yang terutang; karena kebatalan atau pembatalan; karena berlakunya suatu syarat pembatalan, yang diatur dalam Bab I buku ini; dan karena lewat waktu, yang akan diatur dalam suatu bab sendiri”.

Penulis dapat menyimpulkan beberapa hal sebagai berikut: 
1) PT SNG mengetahui bahwa PT HPL telah melakukan pembayaran terhadap utangnya, yang mana menurut teori pengetahuan (vernemings theorie), kesepakatan terjadi pada saat pihak yang melakukan pembayaran mengetahui bahwa pembayarannya telah diketahui oleh pihak yang menerima pembayaran tersebut, atau dapat diartikan PT SNG telah sepakat atau setuju untuk menerima pembayaran tersebut;

2) Walaupun PT SNG mengeluarkan surat pernyataan penolakan pembayaran yang telah dilakukan oleh PT HPL namun dengan tindakannya tidak mengembalikan uang yang telah ditransfer oleh PT HPL tersebut hingga putusan Peninjauan Kembali dibacakan, dan oleh karena PT SNG telah menerima secara diam-diam pembayaran dari PT HPL. Maka berdasarkan ketentuan dalam Pasal 1381 Kitab Undang- Undang Hukum Perdata, pembayaran yang dilakukan oleh PT HPL menyebabkan perikatannya dengan PT SNG menjadi hapus, dan oleh karena hal tersebut piutang PT SNG terhadap PT HPL menjadi hapus pula, demikian PT SNG tidak dapat disebut lagi sebagai kreditor dari PT HPL. Oleh sebab itu syarat adanya 2 (dua) kreditor atau lebih yang diwajibkan oleh peraturan perundang-undangan menjadi tidak terpenuhi.

7. Pernyataan pailit dilakukan oleh pengadilan khusus yang disebut dengan "Pengadilan Niaga"

Pengadilan yang berwenang memutus perkara Kepailitan dan Penundaan Kewajiban dan Pembayaran Utang adalah Pengadilan Niaga. Permohonan pernyataan pailit diajukan kepada Ketua Pengadilan Niaga. PT OGS dan PT SNG dengan surat permohonannya tertanggal 4 Maret 2010, yang ditandatangani oleh Kuasa Hukumnya mendaftarkan permohonannya di Kepaniteraan Pengadilan Niaga pada Pengadilan Negeri Jakarta Pusat di bawah Register Nomor: 16/PAILIT /2010/PN.NIAGA.JKT.PST. Sehingga syarat pernyataan pailit dilakukan oleh oleh Pengadilan Niaga terpenuhi.

8. Permohonan pernyataan pailit diajukan oleh pihak yang berwenang

Adapun pihak-pihak yang berwenang untuk mengajukan suatu permohonan pailit terhadap Debitor adalah sebagai berikut:
a. Pihak Debitor;
b. Satu atau lebih Kreditor;
c. Jaksa untuk kepentingan umum;
d. Bank Indonesia jika debitornya bank; 
e. Bapepam (sekarang Otoritas Jasa Keuangan) jika debitornya adalah perusahaan efek, bursa efek, lembaga kliring dan penjaminan, dan lembaga penyimpanan dan penyelesaian; atau

f. Menteri Keuangan jika debitornya perusahaan asuransi, reasuransi, dana pensiun, dan Badan Usaha Milik Negara yang bergerak di bidang kepentingan publik.

Permohonan kepailitan tersebut wajib diajukan melalui kuasa hukum / advokat dari pemohon kecuali jika pemohonnya adalah Kejaksaan, Bank Indonesia, Bapepam (sekarang Otoritas Jasa Keuangan), atau Menteri Keuangan.

Dalam kasus ini, PT OGS dan PT SNG sebagai kreditor dari PT HPL berwenang mengajukan permohonan kepailitan pada kepaniteraan Pengadilan Niaga di Pengadilan Negeri Jakarta Pusat dengan melalui kuasa hukumnya masing-masing dan berturut-turut yaitu Soenyoto, SH. dan Sugeng Purwanto, SH. Berdasarkan uraian-uraian tersebut di atas, syarat permohonan pernyataan pailit yang diajukan oleh satu atau lebih kreditor telah terpenuhi.

Berdasarkan uraian-uraian tersebut di atas dapat disimpulkan bahwa penerapan syarat kepailitan menurut ketentuan dalam Pasal 2 ayat (1) UU No. 37 Tahun 2004 terhadap kepailitan PT HPL tidak memenuhi seluruh persyaratan yuridis kepailitan yang diwajibkan, adapun syarat yang tidak terpenuhi adalah syarat adanya 2 (dua) kreditor atau lebih, kondisi ini terjadi karena pada saat putusan Pengadilan Niaga tanggal 31 Maret 2010 dibacakan oleh majelis hakim status PT HPL sebagai Debitor hanya memiliki 1 (satu) kreditor yakni PT OGS.

Berdasarkan hal-hal tersebut di atas, maka Penulis berpendapat bahwa majelis hakim dalam putusan Pengadilan Niaga Nomor 16 / PAILIT. 2010/PN. NIAGA.JKT.PST kurang tepat dalam menerapkan ketentuan Pasal 2 ayat (1) UU No. 37 Tahun 2004. Oleh karena tidak terpenuhinya syarat- syarat yuridis kepailitan yang diwajibkan oleh peraturan perundang-undangan yang berlaku maka seharusnya majelis hakim pada Pengadilan Niaga Jakarta Pusat tidak seharusnya menyatakan PT HPL pailit dengan segala akibat hukumnya.

\section{Akibat Hukum dari Pembayaran Utang PT. Hendratna Plywood kepada PT.}

\section{Samudra Naga Global terkait Kepailitan Yang Sudah Didaftarkan Permohonan}

\section{Pailitnya di Pengadilan Niaga pada Pengadilan Negeri Jakarta Pusat}

Dalam ketentuan Pasal 2 ayat (1) UU No. 37 Tahun 2004 diatur bahwa Debitor yang mempunyai 2 (dua) Kreditor atau lebih dan tidak membayar lunas sedikitnya satu utang yang telah jatuh waktu dan dapat ditagih, dinyatakan pailit dengan putusan Pengadilan, baik atas permohonannya sendiri maupun atas permohonan satu atau lebih kreditornya. Hal ini 
Nur Fauzia, Tinjauan Yuridis Terhadap Penolakan Pembayaran Utang Oleh Kreditor Pada Saat Permohonan Pailit Diajukan (Studi Kasus: Kepailitan PT. Hendratna Plymood)

berarti, syarat kepailitan yaitu adanya minimal 2 (dua) kreditor atau lebih dan adanya satu utang yang telah jatuh waktu dan dapat ditagih wajib dipenuhi pada saat putusan pailit dibacakan.

Putusan pernyataan pailit dapat mengakibatkan Debitor yang dinyatakan pailit kehilangan segala hak keperdataannya untuk menguasai dan mengurus harta kekayaan yang telah dimasukan ke dalam harta pailit. ${ }^{15} \mathrm{Hal}$ ini dapat dilihat dari adanya kewenangan Kurator untuk mengurus dan atau melakukan pemberesan harta pailit sejak tanggal putusan pailit diucapkan meskipun terhadap putusan tersebut diajukan upaya hukum berupa kasasi atau peninjauan kembali. Setiap perikatan Debitor yang terbit atau lahir setelah putusan pailit dibacakan maka perikatan tersebut tidak dapat dibayarkan dari harta pailit. Jika ketentuan ini dilanggar oleh si Debitor pailit, maka perbuatannya tersebut tidak akan mengikat harta pailit tersebut, kecuali perikatan yang dibuat tersebut mendatangkan keuntungan terhadap harta pailit.

Dapat disimpulkan bahwa selama belum terdapat putusan hakim terhadap permohonan pernyataan pailit seorang Debitor, maka Penulis berpendapat Debitor masih berwenang untuk melakukan pengelolaan dan pengurusan termasuk pemindah tanganan seluruh harta kekayaannya. kewenangan itu baru hilang setelah Pengadilan Niaga dalam putusannya menyatakan Debitor pailit. ${ }^{16}$ Sehubungan dengan hal tersebut, PT HPL telah melakukan pembayaran utangnya kepada PT SNG sebelum adanya putusan pailit dengan demikian dapat disimpulkan bahwa pembayaran PT HPL kepada PT SNG adalah sah secara yuridis.

Akan tetapi pembayaran oleh PT HPL kepada PT SNG tersebut masih dapat dibatalkan, karena menurut ketentuan dalam Pasal 45 UU No. 37 Tahun 2004 dinyatakan bahwa pembayaran suatu utang yang sudah dapat ditagih hanya dapat dibatalkan apabila dapat dibuktikan bahwa:

a. Penerima pembayaran mengetahui bahwa permohonan pernyataan pailit Debitor sudah didaftarkan, atau

b. Dalam hal pembayaran tersebut merupakan akibat dari persekongkolan antara debitor dan kreditor dengan maksud menguntungkan kreditor tersebut melebihi kreditor lainnya.

${ }^{15}$ Ahmad Yani dan Gunawan Widjaja, Kepailitan (Seri Hukum Bisnis), Jakarta : Rajagrafindo Persada, 2004, hal. 30

${ }^{16}$ Sultan Remy Sjahdeini, OpCit, hal 156 
Nur Fauzia, Tinjauan Yuridis Terhadap Penolakan Pembayaran Utang Oleh Kreditor Pada Saat Permohonan Pailit Diajukan (Studi Kasus: Kepailitan PT. Hendratna Plymood)

Lebih lanjut dalam ketentuan Pasal 47 ayat (1) UU No. 37 Tahun 2004 dinyatakan bahwa yang dapat mengajukan tuntutan pembatalan berdasarkan ketentuan Pasal 41 sampai dengan Pasal 46 UU No. 37 Tahun 2004 adalah Kurator. Dan tidak ada satu ketentuan dalam UU No. 37 Tahun 2004 yang menyatakan bahwa Kreditor dapat mengajukan tuntutan pembatalan terkait hal tersebut di atas, Kreditor hanya dimungkinkan untuk mengajukan bantahan terhadap tuntutan Kurator tersebut (jika ada). Menurut penafsiran terhadap ketentuan dalam Pasal 47 ayat (1) UU No. 37 Tahun 2004 tersebut, diketahui bahwa apabila Kreditor menginginkan agar dilakukan permohonan pembatalan sebagaimana dimaksud dalam Pasal 41 sampai dengan Pasal 46 UU No. 37 Tahun 2004, Kreditor dapat memintanya kepada Kurator untuk mengajukan permintaan pembatalan pembayaran yang telah dilakukan Debitor tersebut. ${ }^{17}$

Lebih lanjut dalam analisisnya dan sesuai dengan ketentuan dalam Pasal 47 ayat (1) UU No. 37 Tahun 2004, Penulis berpendapat bahwa tindakan penolakan pembayaran yang dilakukan oleh PT SNG tidak dapat dianggap sebagai suatu tindakan pembatalan pembayaran suatu utang.

Berdasarkan fakta-fakta hukum dalam persidangan diketahui bahwa pembayaran utang yang dilakukan oleh PT HPL kepada PT SNG tersebut tidak pernah dikembalikan oleh PT SNG bahkan sampai putusan Peninjauan Kembali dibacakan. Dengan demikian, Penulis berpendapat bahwa penolakan pembayaran oleh PT SNG tersebut yang tidak diikuti dengan tindakan pengembalian uang yang diterimanya merupakan suatu tindakan penerimaan secara diam-diam yang dilakukan oleh PT SNG sehingga pembayaran yang dilakukan oleh PT HPL sebelum adanya putusan pailit adalah sah secara hukum dan penerimaan pembayaran secara diam-diam yang dilakukan oleh PT SNG menyebabkan perikatannya dengan PT HPL menjadi hapus demikian berakibat Kreditor yang awalnya berjumlah 2 (dua) Kreditor menjadi hanya berjumlah 1 (satu) kreditor yang memenuhi persyaratan sebagai Kreditor.

Sedangkan keluarnya Putusan Pengadilan Niaga Nomor 16/PAILIT.2010/PN.NIAGA.JKT.PST yang menyatakan bahwa pembayaran utang yang dilakukaon leh PT HPL kepada PT SNG jauh lebih kecil jumlahnya dibandingkan dengan jumlah hutang terhadap PT OGS bukan merupakan suatu perbuatan yang beritikad baik, melainkan dipandang sebagai upaya penghindaran persyaratan pernyataan pailit adalah tidak sesuai dengan UU No. 37 Tahun 2004. Penulis berpendapat bahwa judex facti tidaklah

${ }^{17}$ Sultan Remy Sjahdeini, Op.Cit., hal 256 
Nur Fauzia, Tinjauan Yuridis Terhadap Penolakan Pembayaran Utang Oleh Kreditor Pada Saat Permohonan Pailit Diajukan (Studi Kasus: Kepailitan PT. Hendratna Plymood)

berhak untuk menilai ada atau tidaknya itikad buruk dalam pembayaran utang yang dilakukan oleh PT HPL dan pelunasan utang merupakan bagian hak asasi Debitor yang mutlak.

Berdasarkan hal-hal yang telah diuraikan sebelumnya, Penulis berpendapat bahwa Penulis tidak setuju dengan Putusan Pengadilan Niaga Nomor 16/Pailit.2010/PN.Niaga.Jkt.Pst yang menyatakan PT HPL pailit dengan pertimbangan majelis hakim bahwa pembayaran dari PT HPL kepada PT SNG bukan merupakan suatu itikad baik, dan karenanya tidak dapat diterima. Penulis berpendapat bahwa judex facti dalam putusannya tidak tepat dalam menerapkan ketentuan dalam Pasal 2 jo. Pasal 45 jo. Pasal 47 ayat (1) UU No. 37 Tahun 2004. Sehingga seharusnya pada saat putusan pailit dibacakan, Debitor terbukti secara nyata hanya memiliki 1 (satu) kreditor yaitu PT OGS, dan dengan tidak dapat dibuktikan adanya kreditor lain dari PT HPL pada saat diputuskannya permohonan pernyataan pailit oleh Pengadilan Niaga, maka seharusnya PT HPL tidak dipailitkan.

Pendapat Penulis ini diperkuat dengan adanya yurisprudensi Mahkamah Agung dan beberapa Putusan Pengadilan Niaga terkait dengan pembayaran salah satu utangnya oleh Debitor sebelum putusan pailit dibacakan, yaitu antara lain:

a. Putusan Mahkamah Agung dalam perkara Leo Andyanto melawan PT Astria Raya Bank No. 26K/N/1999 tanggal 12 September 1999, yang menyatakan bahwa syarat Pasal 1 ayat 1 UU No. 4 Tahun 1998, adanya 2 (dua) atau lebih Kreditor tidak terpenuhi, karena itu permohonan pernyataan pailit ditolak oleh Mahkamah Agung Republik Indonesia;

b. Putusan Mahkamah Agung dalam perkara PT Kreasi Tifadata melawan PT. Kujang Arlita No. 867 K/Pdt.Sus/2010 tanggal 19 November 2010, yang menyatakan bahwa Pemohon Kasasi tidak dapat membuktikan adanya kreditur lain, sehingga tidak memenuhi ketentuan dalam Pasal 2 ayat (1) UU No. 37 Tahun 2004, sehingga permohonan kasasi yang diajukan oleh Pemohon Pailit harus ditolak;

c. Putusan Pengadilan Niaga dalam perkara PT Bank Global International Tbk. melawan PT Inter World Steel Mills Indonesia, Ong Ka Bee, Wong Kam Lim. Nomor 12/Pailit.2003/ PN.Niaga/Jkt.Pst, yang menyatakan bahwa kreditor sebagai pihak yang mengajukan permohonan pernyataan pailit tidak dapat membuktikan adanya kreditor lain, sehingga permohonannya ditolak oleh Pengadilan Niaga;

d. Putusan Pengadilan Niaga dalam perkara PT Bank UOB Indonesia melawan Lukman Priosoetanto \& Soenaryo Prioseotanto No. 38 / Pailit/2007/PN.Niaga.Jkt.Pst, yang 
Nur Fauzia, Tinjauan Yuridis Terhadap Penolakan Pembayaran Utang Oleh Kreditor Pada Saat Permohonan Pailit Diajukan (Studi Kasus: Kepailitan PT. Hendratna Plymood)

menyatakan bahwa Pengadilan Niaga menolak permohonan pernyataan pailit yang diajukan oleh Kreditor, karena ternyata Kreditor tidak dapat membuktikan adanya Kreditor lain sebagaimana yang didalilkan oleh Kreditor.

\section{E. Tinjauan terhadap "Penolakan" Pembayaran Utang Yang Dilakukan oleh PT. Samudra Naga Global Dikaji Dari Konsep Itikad Baik}

Dalam UU No. 37 Tahun 2004 maupun peraturan perundang-undangan lain yang berlaku di Indonesia, tidak ada ketentuan yang melarang Debitor untuk melakukan pelunasan utang yang dimiliki terhadap Kreditornya, termasuk pelunasan yang dilakukan selama proses permohonan kepailitan sedang berlangsung. Dalam kasus ini, PT HPL telah melakukan pembayaran lunas terhadap utangnya kepada PT SNG pada saat proses kepailitan di Pengadilan Niaga sedang berlangsung, namun PT SNG menyatakan menolak pembayaran utang yang telah dilakukan oleh PT HPL tersebut dan penolakan PT SNG tersebut tidak diikuti dengan pengembalian uang yang telah dibayarkan oleh PT HPL.

Dalam pertimbangannya majelis hakim pada Pengadilan Niaga berpendapat bahwa "pembayaran utang yang dilakukan oleh PT HPL kepada PT SNG jauh lebih kecil jumlahnya dibandingkan dengan jumlah hutang terhadap PT OGS, sehingga tindakan pembayaran tersebut bukan merupakan perbuatan itikad baik". Jika dilihat dari pendapat majelis hakim tersebut dapat disimpulkan bahwa majelis hakim tidak pernah menyatakan pembayaran yang dilakukan oleh PT HPL kepada PT SNG adalah tidak sah, namun yang dipermasalahkan adalah PT HPL membayar utang yang jumlahnya lebih kecil yaitu utang kepada PT SNG. Penulis berpendapat bahwa majelis hakim dengan pendapatnya ini kurang tepat dalam menerapkan ketentuan peraturan perundang-undangan yang berlaku, dikarenakan seperti yang dijelaskan sebelumnya tidak ada satu ketentuanpun dalam peraturan perundang-undangan di Indonesia yang melarang Debitor untuk membayar utangnya kepada Kreditornya, dan tidak ada pula larangan bagi PT HPL untuk membayar utang yang jumlahnya lebih kecil kepada PT SNG terlebih dahulu daripada utangnya kepada PT OGS, sehingga pendapat majelis hakim terkait pembayaran PT HPL tersebut berdasarkan itikad yang tidak baik adalah sesuatu yang sangat subjektif sifatnya dan tidak didasarkan pada norma-norma hukum yang berlaku.

Berikut pada kesempatan ini pula Penulis bermaksud untuk menjelaskan secara singkat mengenai konsep itikad baik itu sendiri. Asas itikad baik berasal dari hukum Romawi yang dikenal sebagai bonafides, bona secara harfiah dapat diartikan sebagai niat, 
Nur Fauzia, Tinjauan Yuridis Terhadap Penolakan Pembayaran Utang Oleh Kreditor Pada Saat Permohonan Pailit Diajukan (Studi Kasus: Kepailitan PT. Hendratna Plymood)

dan fides secara harfiah dapat diartikan sebagai jujur. Di Indonesia dalam Kitab UndangUndang Hukum Perdata mempergunakan istilah itikad baik dalam 2 (dua) pengertian, yaitu pertama dalam pengertian subjektif yang mana dapat diartikan sebagai suatu kejujuran, hal ini terdapat dalam pasal 530 Kitab Undang-Undang Hukum Perdata dan seterusnya yang mengatur mengenai kedudukan berkuasa (bezit), itikad baik dalam arti subjektif ini dapat pula diartikan sebagai sikap batin atau suatu keadaan jiwa. ${ }^{18}$ Menurut Siti Ismijati Jenie, pengertian kedua yaitu itikad baik dalam arti objektif yang mana dapat diartikan sebagai kepatutan, hal ini dirumuskan pula dalam Pasal 1338 ayat 3 Kitab Undang-Undang Hukum Perdata yang berbunyi sebagai berikut "suatu perjanjian harus dilaksanakan dengan itikad baik". Mengutip Pasal 1338 ayat 3 tersebut, lebih lanjut Beliau memaparkan kejujuran (itikad baik) tidak terletak pada keadaan jiwa manusia, akan tetapi terletak pada tindakan yang dilakukan oleh kedua belah pihak dalam melaksanakan janji, jadi kejujuran disini bersifat dinamis, "kejujuran dalam arti dinamis atau kepatutan ini berakar pada sifat peranan hukum pada umumnya, yaitu usaha untuk mengadakan keseimbangan dari berbagai kepentingan yang ada dalam masyarakat.

Dalam perkembangannya itikad baik telah menjadi asas yang penting dalam hukum kontrak dan diterima di berbagai sistem hukum, akan tetapi itikad baik masih merupakan sesuatu yang kontraversial. Perdebatan utama adalah yang berkaitan dengan definisi itikad baik itu sendiri, dalam kenyataannya sangat sulit menemukan pengertian yang jelas tentang itikad baik. Pendapat Allan E. Farsnworth bahwa dimana itikad baik diterima, pasti timbul perbedaan dalam mengartikan itikad baik tersebut. ${ }^{19}$ Akibatnya tidak ada makna tunggal dari definisi itikad baik. Dalam hukum kontrak sendiri definisi dari itikad baik sangat sedikit, bahkan untuk negara-negara civil law yang memasukan konsep itikad baik ke dalam kitab undang-undang hukum perdata hanya mengatur sedikit saja. Pasal 242 Handelsgesetzbuch (HGB) Jerman, Pasal 1134 ayat 3 Civil Code Perancis, dan 1374 ayat 3 Burgerlijk Wetboek Belanda (lama) serta Pasal 1338 ayat 3 Kitab Undang-Undang Hukum Perdata hanya menyebutkan bahwa semua kontrak dilaksanakan dengan itikad baik. Oleh karena hal tersebut untuk dapat memahami itikad baik yang lebih jelas harus dilihat pada penafsiran itikad baik dalam praktik pengadilan secara kasus demi kasus.

${ }^{18}$ Siti Ismijati Jenie, Pidato Pengukuhan berjudul "Itikad Baik, Perkembangan Dari Asas Hukum Khusus Menjadi Asas Hukum Umum Di Indonesia”, pada tanggal 10 September 2007

${ }^{19}$ Eric M. Holmes, "A Contextual Study of Commercial Good Faith : Good Faith Disclosure in Contract Formation", University of Pittsburgh Law Review, Vol 39 No. 3 (1978), hal 400 
Nur Fauzia, Tinjauan Yuridis Terhadap Penolakan Pembayaran Utang Oleh Kreditor Pada Saat Permohonan Pailit Diajukan (Studi Kasus: Kepailitan PT. Hendratna Plymood)

Merujuk pada ketentuan dalam Pasal 1338 Ayat 3 Kitab Undang-Undang Hukum Perdata, yurisprudensi, dan doktrin pada umumnya mengartikan itikad baik bersifat objektif jika berada di ranah perikatan, dan dalam ranah hukum benda itikad baik diartikan sebagai sesuatu yang bersifat subjektif. ${ }^{20}$ Itikad baik dalam pengertian subjektif adalah kejujuran seseorang dalam melakukan sesuatu perbuatan hukum, sedangkan dalam pengertian objektif adalah pelaksanaan suatu perjanjian harus didasarkan pada norma kepatuhan atau apa-apa yang dirasakan sesuai dengan yang patut dalam masyarakat. ${ }^{21}$ Itikad baik dalam peraturan perundang-undangan kita merupakan Das Sollen yang harus direfleksikan dalam hukum positif.

Berdasarkan uraian tersebut di atas, Penulis berpendapat bahwa majelis hakim dalam putusannya tersebut memandang itikad baik sebagai sesuatu yang bersifat subjektif, yang mana hal tersebut tidak sesuai dengan perkara PT HPL dikarenakan hubungan antara PT HPL dengan para kreditornya adalah hubungan dalam ranah perikatan sehingga seharusnya majelis hakim memandang itikad baik sebagai sesuatu yang bersifat objektif bukan sesuatu yang bersifat subjektif. Itikad baik dalam konsep hukum yang berlaku di Indonesia harus dapat direfleksikan dalam hukum positif yang ada, yang mana telah diuraikan sebelumnya bahwa tidak ada ketentuan yang melarang pembayaran utang pada saat proses kepailitan berlangsung dan tidak ada pula larangan bagi Debitor untuk membayar utang yang jumlahnya lebih kecil kepada Kreditornya, maka pendapat majelis hakim dalam perkara PT HPL tersebut tidak didasarkan pada norma-norma hukum yang cukup.

Selain hal tersebut di atas, tindakan PT SNG yang menyatakan menolak pembayaran utang oleh PT HPL tanpa diikuti dengan pengembalian uang yang telah diterimanya bahkan hingga putusan Peninjauan Kembali dibacakan, menurut Penulis merupakan suatu bentuk itikad tidak baik dari PT SNG. Penulis berpendapat tujuan dari penolakan PT SNG tersebut adalah untuk mempailitkan PT HPL bukan untuk mendapatkan pelunasan terhadap piutang yang dimilikinya. Hal ini jelas sekali bertentangan dengan asas keseimbangan yang dianut dalam UU No. 37 Tahun 2004 yaitu terjadinya penyalahgunaan pranata dan lembaga kepailitan oleh kreditor yang tidak beritikad baik.

\footnotetext{
${ }^{20}$ Anonim, "Perlu ada Kepastian Hukum Soal Iktikad Baik", http://www.hukumonline.com/berita/baca/lt524946678eefe/perlu-ada-kepastian-hukum-soal- iktikad-baik, 26 November 2019

${ }^{21}$ Meliala Qirom Samsudin, “Itikad Baik”, http://kamusbisnis.com/arti/itikad-baik/, 26 November 2014
} 
Nur Fauzia, Tinjauan Yuridis Terhadap Penolakan Pembayaran Utang Oleh Kreditor Pada Saat Permohonan Pailit Diajukan (Studi Kasus: Kepailitan PT. Hendratna Plymood)

\section{F. Kesimpulan}

1. Berdasarkan hasil analisis terhadap Putusan Pengadilan Niaga pada Pengadilan Negeri Jakarta Pusat Nomor: 16/PAILIT/2010/PN.NIAGA.JKT.PST jo. Putusan Kasasi Mahkamah Agung Republik Indonesia No. 428 K/Pdt.Sus/2010 jo. Putusan Peninjauan Kembali Mahkamah Agung Republik Indonesia No. 034 PK/Pdt.Sus/2011 berturut-turut yang diucapkan dalam persidangan tetanggal 7 April 2010, 17 Juni 2010, dan 26 April 2011 yang pada intinya dengan segala pertimbangan hakim menjatuhkan putusan pailit kepada PT HPL dengan segala akibat hukumnya adalah kurang tepat atau tidak sesuai dalam penerapan syarat- syarat yuridis pengajuan permohonan pailit sebagaimana dimaksud dalam ketentuan Pasal 2 ayat (1) UU No. 37 Tahun 2004. Penulis dalam analisisnya berpendapat bahwa syarat adanya minimal 2 (dua) kreditor atau lebih tidak terpenuhi, dikarenakan kondisi pada saat putusan Pengadilan Niaga pada Pengadilan Negeri Jakarta Pusat Nomor: 16/PAILIT/2010/PN.NIAGA.JKT.PST tanggal 7 April 2010 dibacakan statusnya PT HPL saat itu hanya memiliki 1 (satu) kreditor saja yakni PT OGS, sedangkan PT SNG telah kehilangan statusnya sebagai Kreditor dengan dilakukannya pembayaran oleh PT HPL kepada PT SNG. Oleh karena tidak terpenuhinya salah satu syarat yuridis kepailitan sebagaimana diatur dalam ketentuan Pasal 2 ayat (1) UU No. 37 Tahun 2004 dan dikuatkan dengan beberapa yurisprudensi yang telah dikeluarkan oleh putusan Mahkamah Agung dan putusan Pengadilan Niaga yang telah disebutkan dalam analisisnya, maka menurut pendapat Penulis seharusnya PT HPL tidak dipailitkan.

2. Akibat hukum yang timbul dari dilakukannya pembayaran utang oleh PT HPL kepada PT SNG pada saat permohonan kepailitan sudah didaftarkan di Pengadilan Niaga pada Pengadilan Negeri Jakarta Pusat adalah sah menurut hukum karena tidak ada satupun ketentuan baik dalam UU No. 37 Tahun 2004 maupun peraturan perundang-undangan lain di Indonesia yang melarangnya hal tersebut. Dalam analisisnya dan berdasarkan beberapa pertimbangan yang ada Penulis berpendapat bahwa Debitor demi hukum kehilangan haknya untuk mengurus dan melakukan perbuatan hukum serta kepemilikan terhadap harta kekayaannya setelah diucapkannya putusan pailit, sehingga setiap tindakan hukum yang dilakukan termasuk pembayaran utang yang dilakukan oleh PT HPL adalah sah menurut hukum dan ditambah dengan dalam putusannya majelis hakim tidak pernah menyatakan tindakan PT HPL tersebut adalah tidak sah. 
3. Dalam pertimbangnya majelis hakim berpendapat bahwa pembayaran utang yang dilakukan oleh PT HPL kepada PT SNG yang jumlahnya lebih kecil dibandingkan dengan utangnya kepada PT OGS adalah bukan merupakan perbuatan itikad baik. Terkait hal ini dalam analisisnya Penulis berpendapat bahwa majelis hakim memandang hal ini secara subjektif tanpa didasarkan pada norma-norma hukum yang berlaku, dimana seharusnya dalam kepailitan PT HPL ini jika majelis hakim hendak menggunakan konsep itikad baik harus dilakukan pertimbangan secara objektif bukan subjektif, ditambah dengan penolakan pembayaran utang yang dilakukan oleh PT SNG tersebut telah terbukti secara nyata dan menyakinkan dengan tidak diikuti pengembalian uang yang diterimanya dari PT HPL tersebut bahkan hingga putusan Peninjauan Kembali diucapkan oleh majelis hakim. Sehingga Penulis dalam kesimpulannya berpendapat bahwa majelis hakim kurang tepat dalam memandang konsep itikad baik terkait kasus ini, dan tindakan penolakan PT SNG tersebut bukanlah suatu perbuatan yang didasarkan pada itikad baik melainkan perbuatan yang didasarkan pada niat untuk mempailitkan PT HPL sehingga terjadinya penyalahgunaan pranata dan lembaga kepailitan oleh kreditor yang tidak beritikad baik.

\section{G. Rekomendasi}

Berdasarkan uraian-uraian tersebut di atas, adapun beberapa saran yang ingin Penulis sampaikan yang sekiranya dapat dijadikan bahan masukan kedepannya adalah sebagai berikut: Pertama, Pengadilan hendaknya dalam memutus suatu perkara kepailitan haruslah lebih cermat dan teliti dalam menerapkan ketentuan-ketentuan dalam UU No. 37 Tahun 2004 sebagai dasar hukum kepailitan, dalam hal syarat jumlah minimum kreditor tidak terpenuhi pada saat putusan pailit dibacakan, maka hendaknya majelis hakim menolak permohonan pailit yang telah diajukan dan menyarankan agar kreditor yang bersangkutan mengajukan gugatan melalui Pengadilan Negeri untuk kasus perdata biasa. Kedua, Pemerintah Republik Indonesia dalam kedudukannya sebagai regulator hendaknya dapat belajar dari kasus- kasus yang pernah ada sebelumnya, sehingga perlu dipertimbangkan apakah diperbolehkan pembayaran utang sebelum putusan pailit dibacakan, jika ternyata nantinya Pemerintah berpendapat bahwa hal semacam ini diperbolehkan atau tidak diperbolehkan, maka hendaknya dibuat suatu peraturan tambahan, dapat dalam bentuk Peraturan Pemerintah, Keputusan Menteri, atau Surat Edaran Mahkamah Agung yang pada intinya mengatur hal tersebut sehingga dapat terciptanya suatu kepastian hukum di Indonesia 
Nur Fauzia, Tinjauan Yuridis Terhadap Penolakan Pembayaran Utang Oleh Kreditor Pada Saat Permohonan Pailit Diajukan (Studi Kasus: Kepailitan PT. Hendratna Plymood)

dan tidak terjadi lagi penyalahgunaan pranata dan lembaga kepailitan oleh Kreditor yang tidak beritikad baik.

\section{H. DAFTAR PUSTAKA}

Kartono. Kepailitan dan Pengunduran Pembayaran. Jakarta: Pridnya Paramita, 1982.

Sastrawidjaja, Man S. Hukum Kepailitan dan Penundaan Kewajiban Pembayaran Utang. Bandung: P.T. Alumni, 2006.

Shubhan, M. Hadi. Hukum Kepailitan: Prinsip, Norma dan Praktek di Pengadilan. Jakarta: Kencana, 2009.

Sjahdeini, Sutan Remi. Hukum Kepailitan: Memahami Failissement Verordening Juncto Undang - Undang nomor 4 tahun 1998. Jakarta: Pustaka Grafiti Utama, 2002.

Soekanto, Soerjono. Pengantar Penelitian Hukum. Jakarta: Universitas Indonesia, 1986 